\title{
XII R. Gorbacheva Memorial Symposium Hematopoietic Stem Cell Transplantation. Gene and Cellular Therapy: an Overview
}

\author{
Boris V. Afanasyev \\ Editor-in Chief, Cellular Therapy and Transplantation \\ R. M. Gorbacheva Memorial Institute of Children Hematology, Oncology and Transplantation, Chair of Hematology, Trans- \\ fusiology and Transplantology, Pavlov First St. Petersburg State Medical University, L. Tolstoy St. 6-8, 197022, St. Petersburg, \\ Russia
}

Phone: $+7(812) 3386265$

E-mail: bvafan@gmail.com

This year, the XII Symposium took place at the Sokos Hotel in St. Petersburg and proceeded in friendly environment and was attended by many widely known specialists in hematopoietic transplantation and adjacent fields.

The Gene Therapy symposium (Hall Athens September 22) was dedicated to some issues of novel cell-based and gene therapeutic products developed in Russia and European countries. A special session concerned technical aspects and legislative issues of cellular and gene therapy. Professor Gerard Wagemaker (Netherlands) presented a comprehensive review Hematopoietic Stem Cell Gene Therapy. He pointed to rapid progress in hematopoietic stem cells as a suitable tool for gene therapy of inherited and acquired immune deficiencies as well as inherited enzyme deficiencies using HIV-1 derived SIN lentiviral vectors which proved to be safe and effective when propagating gene-transduced autologous hematopoietic stem cells, and their long-term functioning in recipients. He described the newly developed gene transfer closed systems, as well as clinical trials aimed for treatment of some inherited immune and metabolic disorders.

Current advances and issues of gene editing were described in the lecture by Prof. Boris Fehse (Hamburg, Germany) entitled CCR5 as a target of gene editing. Successful allogeneic SCT in HIV patients is now feasible only with CCR5 $\Delta 32$ producing a lot of early complications, thus presuming transplantation of autologous genetically protected cells with in vitro CCR5 knockout, performed by means of TALEn or CRISPR/Cas nucleases. In vitro preparation of gene-modified cells, their safety (e.g., off-target effects) and potential efficacy in HIV infection are now tested in preclinical studies.

Hans-Peter Kiem (Seattle, USA), a known specialist in gene therapy, presented a lecture "Novel target for hematopoietic stem cell gene therapy and editing" describing sufficient technical details of gene transfection and appropriate GLP systems for potential clinical usage. Autologous transplantation of HSCs in nonhuman primates (NHPs) is proposed as the best preclinical test model for gene therapy.

Professor Boris V. Afanasyev (St. Petersburg) held a lecture. Current status and perspectives of immunotherapy in patients with different malignancies concerning various types of immune therapy now applied in clinical oncology, from allogeneic hematopoietic stem cell transplantation (alloHSCT) to adoptive cell therapy and CAR-T cells. Special attention was given to clinical efficiency of novel drugs including bifunctional antibodies and immune checkpoint inhibitors (PD-1/PD-1L, CTLA4 etc.).

Evolving aspects of immune therapy were represented, mostly, by a group of young scientists from Novosibirsk and St. Petersburg. A report Antitumor activity of CD19-chimeric antigen receptor expressing $T$ cells was presented by P. Gershovich (Biocad, St. Petersburg). He discussed optimal industrial workflow for production of CD19-specific CAR T cells as well as standard in vitro assays to assess antitumor activity towards target malignant cells as it is done at the BioCad factory.

Anna K. Vladimirova specified the details of CAR-T Cell preparation in her report Approaches to design of CD1 - chimeric antigen-binding domain of CAR cells. Optimization of $\mathrm{scFv}$ gene fragments in order to provide high expression of antigen-binding domains on CD19 T cell lines was discussed.

Alexey Petukhov (St. Petersburg), a specialist from the Almazov Medical Centre, provided a report on the "Algorithm for searching new targets for CAR-T cell therapy", considering a variety of screening assays (NGS, mass-spectrometry, microarrays), for detection of specific target antigens on different kinds of human cells.

Anton Chikaev, an immunogeneticist from the Institute of Molecular and Cellular Biology (Novosibirsk) presented a novel view on gene-engineered natural killer cells, i.e., NK-derived cell lines able to block the CD47 molecule on the tumor cells. The s.c. ECAR - YT cells may produce CD47/SIRPa blockers, thus enhancing killing of tumor cells, at least, in murine models.

A worker from the same institution, Tatiana Belovezhets, continued the discussion with a Quest for the optimal NKcell line as a CAR carrier. In general, the NK cell lines are regarded as better carriers of chimeric antigen receptors (CARs), due to a sum of their biological benefits if compared to CAR-T cells. The NK-92 cell line is considered most promising and undergoes clinical trials in Germany and China. Moreover, Andrey Gorchakov presented his vision 
of alternative targets for CARs "Adnectin-based CARs: pros and cons" showing potential benefits of schedules using the humanized FnCARs instead of murine scFv-CARs targeting PSCA or PSMA, VEGFR2, IGF-1R, CEA or other markers expressed in solid tumors. Fn3 modules may function as antigen-recognition modules of CARs. This topic was successfully accomplished by S. Kulemzin who revived the hopes for natural killers as CAR carriers by current advances in gene editing (Forging the Natural killer with genome editing.

The main part of Symposium was opened by the Thomas Büchner Memorial Lecture presented by Prof. Valery Savchenko which concerned treatment of acute myeloblastic leukemia (AML) which has made a great success over last decades. Allogeneic HSCT also contributed to dramatic increase in long-term survival in AML patients, being a continuation of "double induction and maintenance", a concept being developed by Th. Büchner for many years. Moreover, factors of "bad" cytogenetics, comorbidities, patient's age etc. do also matter in prognosis and relapse-free survival.

A lecture by Prof. Robert P. Gale Is MRD-testing in AML the greatest advance since the discovery of fire? highlighted the uncertainty and associative mode of predictions based on many parameters, including minimal residual disease (MRD) measured by flow cytometry, PCR, or NGS. Prof. Gale stressed a known fundamental difference between statistics and how physicians make decisions, thus claiming for cautions when interpreting the MRD results.

Professor Arnon Nagler from Israel presented a lecture Prevention and Treatment of AML Relapse after Allogeneic Stem Cell Transplantation. Taking into account poor survival of relapsing AML patients despite allo-HSCT, it is proposed to continue maintenance and prophylactic therapy posttransplant, especially in patients with high-risk leukemia or with RIC conditioning. Donor lymphocyte infusions and some new drugs may increase the survival in AML

Professor R. Hehlmann (Germany) summarized the existing data in a lecture CML in 2018 with special attention to the terminal phase. Imatinib and other kinase inhibitors have postponed the terms of CML progression and blast crisis. High-risk accessory chromosomal aberrations have a negative impact on survival and are closely associated with blast crisis and disease progression.

Immune therapy in oncology, an actual topic, was discussed by Prof. H.-J. Kolb in his review lecture Allogeneic stem cell transplantation for the treatment of solid tumors? Donor lymphocyte infusions are now regularly used for prevention of relapses in leukemia, thus exploiting "graft versus leukemia” effect. Specific cellular populations, e.g., Regulatory T cells, myeloid-derived suppressor cells, type 2 macrophages may be also involved at various steps of immune surveillance and response. Over last years, targeted drugs, especially PD-1 inhibitors have been successfully applied for treatment of melanoma and some other immunogenic tumors.

Professor A. Madrigal (London, UK) presented a report on The immunobiology of cell therapy and the umbilical cord unique cells. This source of hematopoietic stem cells has been used for decades. Cord blood (CB) cells contain wide range of potential antitumor cells, e.g., NK, Tregs, antigen-specific
$\mathrm{T}$ cells etc. Some protocols for CB cultures and expansion are described, as well as several clinical trials. CAR-T cells derived from cord blood cells are also a promising tool of therapy. Some other immune treatments are discussed, i.e., neo-antigen vaccination, and use of checkpoint inhibitors. Interesting data on applications of expanded NK cells for immunotherapy are also summarized.

A lecture by Professor A. R. Zander (Hamburg, Germany) was concerned novel approaches to multiple myeloma treatment: Cellular Therapy for Multiple Myeloma - is there still a place for allogeneic stem cell transplantation? Two main types of cellular therapy or their sequential use are in scope (autologous SCT, allogeneic SCT), sometimes supplemented by donor lymphocyte infusions with various efficiency observed by different working groups. Application of CAR T-cells still is under clinical trials, and some adverse effects (cytokine release syndrome, neurotoxicity) and possible reasons for immunotherapy failure are also discussed.

A comprehensive lecture From Maxi to Mini: maintaining balance between efficacy, toxicity and intensity was presented by Professor B. V. Afanasyev (St. Petersburg). He has followed in brief the history of allo-HSCT, from myeloablative conditioning with bone marrow replacement to reduced-intensity treatment with immunotherapeutic components augmented by donor lymphocyte infusions. This strategy has led, e.g., to increased age of patients subjected to allo-HSCT. In view of high relapse risk, multiple 'bridging' strategies to allo-HSCT, e.g., in Hodgkin's disease (HD) are discussed. Successful results on HD were obtained with Brentuximab. Hence, the use of RIC, MAB, ICIs, targeted therapy in various combinations with HSCT may be more effective and less toxic in some instances.

At the session Different aspects of HSCT, an impressive report was presented by Prof. J. Mattsson (Stockholm) entitled: Allogeneic SCT - the devil is in the details: More transplants, improved outcomes and lower costs. After pointing to some factors causing early post-HSCT mortality, he reported several convincing reasons for using home care which may decrease complication rates, and mortality among this cohort. J.Mattsson also told about potential efficiency of decidual stromal cells against GVHD in humans.

Dr. Johan Törlén (Stockholm) compared Results of a prospective randomized trial comparing CyA/Mtx and Tac/Sir as GVHD prophylaxis after HSCT showing comparable outcomes with CsA/Mtx in patients after matched related/ unrelated HSCT. He did not find any significant differences between the 2 regimens in viral reactivation, or septicemias. Moreover, the dynamics of thymocyte differentiation markers TREC or KREC were not affected by the type of GVHD-prophylaxis.

A useful lecture Histopathological and molecular findings in the bone marrow of MPN after SCT was pesented by Prof. Hans Kreipe (Hannover). Multiple mutations in myeloproliferative neoplasia (MPN) are reviewed as well as their probable clinical significance for development of myelofibrosis. Longstanding PMF and PV with acelleration frequently have MPN driver mutations. Meanwhile, extensive fibrosis resolves within up to 6 month following successful allo-HSCT, being a good pathological marker. 
Several short reports on current local developments were made by clinicians from R. Gorbacheva Research Institute (St. Petersburg). Dr. O. Pirogova told about AL amyloidosis: novel approaches to diagnosis and treatment. The place of HSCT. Dr. Maria Barabanshchikova presented The place of allogeneic hematopoietic stem cell transplantation for patients with myelofibrosis in the era of JAK1/JAK2 inhibitors. Dr. N. Tsvetkov described his observations concerning Preand posttransplant therapy in adult MDS patients.

Prof. Manuel Abecasis (Lisboa) reported quite interesting data about developments of allogeneic bone marrow transplantation in Portugal (1987-2016): HSCT at 30: how it has evolved and lessons learned in our centre. The report included data about 1854 transplanted patients (793 alloHSCTs, mostly from related donors). A large donor registry (ca. 400000 persons) now exists in Portugal. Overall and relapse - free survival rates increased by the last decade.

Professor T. Ruutu (Finland) presented a comprehensive review Recent developments in transplant-associated thrombotic microangiopathy (TA-TMA) associated with posttransplant endothelial damage and is difficult to diagnosis. Role of schistocytosis as a diagnostic marker is being discussed. In some TA-TMA patients, the complement is activated, thus presuming Eculizumab treatment.

Dr. Ken Ishiyama (Japan) reported his viewpoint in the lecture: Posttransplant immune-mediated hematopoietic failure: A common cause of late graft failure in patients with complete donor chimerism. Pathogenesis of late hematopoietic graft failure in not clear. In some cases (similar to aplastic anemia) it is associated with (GPI-AP)-deficient (PNH-type) cells, and/or HLA allele-lacking leukocytes (HLA-LLs). The immune bone marrow failure may be cured by immunosuppressive therapy, without second HSCT.

Dr. D. Motorin (St. Petersburg) presented a report Hematopoetic recovery after haploidentical stem cell transplantation concerning factors influencing clinical outcomes in the patients transplanted for ALL, AML and CML. Haploidentical HSCT is associated with longer platelet recovery compared with matched related SCT.

A session Basic Research was opened by Dr. Magne Borset (Norway) who presented his lecture Hypoglycemia and hypoxia: how can cancer cells survive? He discussed several appropriate biochemical postulates and findings (predominance of glycolysis in cancer cells, special biosynthetic role of serine and glycine with enriched Glute1 and CD98; promotion of glycolysis and high ATP production by PRL-3), as exemplified by myeloma cells. A conclusion is made that PRL-3 and enzymes in the serine/glycine pathway may be promising target in cancer treatment.

Professor B. Fehse (Hamburg) in his report Genetic marking to study malignant processes concerned applications of gene marking for current improvement of gene therapy advances, in particular when working with lentiviral vectors (LeGo vectors). Considered are: colour (RGB) marking to analyse clonal outgrowth, and DNA barcoding to track malignant clones (Barcoded LeGO vectors). Genetic barcoding is used, e.g., to study clonality of cell cultures. Optical barcoding by fluorescent proteins is now in vitro introduced. Dr. Claudia Lange proceeded with her communication MSC-derived ex- tracellular vesicles in hemato-oncology concerning complex protein composition and spectrum of gene activation in extracellular vesicles (EV) derived by mesenchymal stem cells as well as in vivo positive effects of EV upon stem cells, e.g., promoting survival of irradiated mice.

A lecture Nongenotoxic conditioning for stem cell transplantation and gene therapy/editing was presented by Professor H.-P. Kiem (Seattle, USA) concerning special conditioning protocols for gene therapy of non-malignant disorders. On the basis of murine experiment, the author proposed an immunotoxin-based conditioning which facilitates engraftment in an autologous transplant model in a comparable manner to known cyclophosphamide conditioning.

Professor N. Mamaev (St. Petersburg) dealt with WT1 expression as a leukemia relapse marker in his lecture Experience and perspectives of molecular monitoring, based on serial measurement of WT1 gene level expression, for evaluation of allo-HSCT and chemotherapy efficacy in AML. He concluded that detection of WT1 mRNA expression is available in all AML patients who are preparing to HSCT presuming its wider use pre- and post HSCT.

Dr. A. Timin reported some experimental data in his communication Functionalization of bone marrow mesenchymal stromal cells by multifunctional microcapsules for targeted drug delivery. The authors propose a new concept of multilayer polyelectrolyte microcapsules intended as drug carriers, activable by different physical agents. Their interactions with human mesenchymal cells are demonstrated.

Pediatric Session started with a lecture by Prof. Alexander Roumyantsev (Moscow) entitled Prospectives for development of pediatric oncology in Russia. The lecture contained multiple data on epidemiology of pediatric cancer in Russia and worldwide, advances in treatment of ALL, lymphomas and some solid tumors in children. Special attention was drawn to organizational aspects of pediatric oncology/ hematology in Russia. Professor A. Maschan (Moscow) presented some new data about prevention of graft failure and dysfunction in pediatric clinic.

Prof B. Pinto Simões (Brazil) shared her clinical experience of Stem cell transplantation in multiple sclerosis (MS), a disabling disease that affects about 2.5 million people worldwide. A concept of resetting immune system allowed application of auto-HSCT. Proportion of the patients with longterm complete response was rather high, in terms of EDSS performance scores.

Prof. Olga Aleynikova (Minsk, Republic of Belarus) presented with a lecture Achievements and prospects of children's oncology and hematology in the Republic of Belarus. The program started in late 90's. First advances were with ALL, lymphoma and AML treatment using European protocols. ECP and mesenchymal stem cells are used as supplementary therapy. Among promising approaches, NK therapy from haploidentical donors is considered. Over 1000 HSCT have been performed in Belarus over the last 20 years.

Dr. I. Markova (St. Petersburg) provided her data in a report Overcoming resistance in pediatric ALL with blinatumom$\boldsymbol{a} \boldsymbol{b}$ where appropriate regimens and timing were proposed for blinatumomab usage. 
Prof. M. Maschan (Moscow) presented primary results concerning the CD19 CAR-T in $r / r$ pediatric ALL: first experience at Dmitriy Rogachev center. The study was performed with autologous leukapheresis cells, followed by enrichment for CD4/CD8 cells, transduction with Lentigen vector, expansion in a closed system. Such point-of-care production of CD19 CAR-T cells is feasible and robust. First 3 patients were safely treated with evident clinical effect observed.

Dr. A. Lawitschka (Vienna, Austria) presented a report GVHD and ECP: aspects for future studies concerning important aspects of conditioning and GvHD in pediatric transplantation, methods of GvHD prophylaxis. Several guidelines on extracorporeal photopheresis for chronic GvHD are discussed, as well as benefits and pitfalls of this therapeutic approach.

Prof. N. Subbotina (Moscow) in her message SCT in pediatric oncology: ways to improve efficacy reported current applications of auto-SCT at different efficiency spoke about pediatric solid tumors, leukemias and lymphomas. Personalization of therapy with regard to age of patient, characteristics of tumors, and appropriate treatment modes are considered. Individual treatment plans are applied for medulloblastoma, Hodgkin's disease, and other pediatric malignancies.

Dr. K. Kirgizov (Moscow) presented a report entitled Hematopoietic stem cell transplantation for pediatric non-malignant hematological disorders and inborn errors describing experience in allogeneic HSCT for treatment of severe anemias, congenital dyskeratosis, Hurler disease and other non-malignant disorders. Personalized conditioning and proper donor selection allow to establish optimal results with long remissions.
A series of short reports at pediatric section was performed by young doctors from the R. Gorbacheva Research Institute: Dr. A. Osipova spoke about the outcomes of allo-HSCT in pediatric MDS patients; Dr. A. Kozlov told about immunotherapy in management of pediatric resistant lymphoproliferative disorders; Dr. O. Goloshchapov reported about fecal microbiota transplantation in patients after HSCT; T. Bykova - on GvHD prophylaxis and treatment in children after allo-HSCT; O. Paina presented own data on allo-HSCT from haploidentical donors in children and adolescents with high-risk leukemias, P. Kozhokar reported results of second allogeneic HSCT in children with high-risk hematological malignancies.

Raisa Gorbacheva Memorial Lecture HSCT in ALL: decision making by MRD and NGS was performed by Professor D. Hoelzer (Frankfurt a.M., Germany). The report included search for diagnostic markers (TCR/IgH rearrangements, surface markers, fusion genes etc.), as well as potential targets for therapy including surface markers, e.g., CD20, CD19, CD22, CD33, or gene aberrations (BCR-ABL, Flt3-mutations). In this context, next-generation sequencing is the most precise tool for searching novel marker mutations. Some new drugs, e.g. venetoclax, are considered for the cases of ALL relapse.

Traditional Section of medical nurses and a Section of medical and social rehabilitation also took place in the frame of Symposium drawing sufficient attention of the participants and audience.

\title{
0бзор докладов на XII симпозиуме «Трансплантация гемопоэти- ческих стволовых клеток. Генная и клеточная терапия»
}

\author{
Борис В. Афанасьев \\ Главный редактор, журнал «Клеточная Терапия и Трансплантация» \\ НИИ Детской Гематологии, Онкологии и Трансплантологии им. Р. М. Горбачевой, кафедра гематологии, трансфузи- \\ ологии и трансплантологии, Первый Санкт-Петербургский государственный медицинский университет \\ им. акад. И. П. Павлова
}

В этом году XII симпозиум проходил в отеле «СокосОлимпия» (Санкт-Петербург) в дружеской обстановке. Его участниками были широко известные специалисты в трансплантации гемопоэтических клеток и смежных областях.

Симпозиум по генной терапии (зал «Афины», 22 сентября) был посвящен некоторым проблемам, возникающим при разработке новых клеточных и генно-терапевтических продуктов в России и странах Европы. Специальное заседание касалось технических аспектов и законодательных проблем клеточной и генной терапии. Проф. Герард Вагемакер (Нидерланды) представил компетентный обзор «Терапия гемопоэтическими стволовыми клетками». ОН отметил быстрый прогресс в применении гемопоэтических стволовых кле- ток (ГСК) в качестве удобного средства генной терапии наследственных и приобретенных иммунодефицитов, а также врожденных энзимных дефектовс помощью самоинактивирующихся (SIN) лентивирусных векторов, происходящих из ВИЧ, которые оказались безопасными и эффективными при размножении генно-трансформированных аутологичных кроветворных клеток, обеспечивая их длительное функционирование у реципиентов. Он также описал новые закрытые системы, а также клинические испытания, направленные на лечение ряда иммунных и метаболических заболеваний.

Современные достижения и проблемы генного редактирования были описаны в лекции проф. Бориса Фезе (Гамбург, Германия) «CCR5 как мишень генного редактирования». Успешная аллогенная трансплантация ге- 
мопоэтических стволовых клеток (ТГСК) у пациентов с ВИЧ-инфекцией возможна сейчас только от доноров с делецией CCR $5 \Delta 32$, при наличии множества ранних осложнений. Это наводит на мысль о трансплантациях аутологичных, генетически защищенных от ВИЧ клеток, с инактивированным геном CCR5, что делают посредством нуклеаз TALEN или CRISPR/Cas. Получение in vitro генно-модифицированных клеток, их безопасность (например, внецелевые эффекты) и потенциальная эффективность при ВИЧ-инфекции сейчас исследуют в процессе доклинических испытаний.

Ханс-Петер Ким (Сиэтл, США), известный специалист

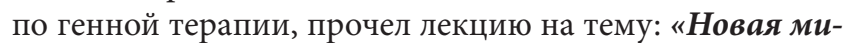
иень для терапии гемопоэтическими стволовыми клетками и генного редактирования» с описанием существенных технических деталей трансфекции генов и систем соответствующих нормам Надлежащей Лабораторной Практики (GLP) для потенциального клинического применения. Аутологичная трансплантация ГСК у обезьян-приматов предлагается в качестве наилучшей доклинической модели для тестирования методов генной терапии.

Проф. Борис В. Афанасьев (Санкт-Петербург) выступил с лекцией «Современное состояние и перспективы иммунотерапии у пациентов с различными злокачественными новообразованиями» относительно различных типов иммунной терапии, применяемой теперь в клинической онкологии, от трансплантации аллогенных ГСК (алло-ТГСК) до адоптивной клеточной терапии и CAR-T-клеток. Особое внимание уделено клинической эффективности новых препаратов, включая бифункциональные антитела и ингибиторы иммунных контрольных точек (PD-1/PD-1L, CTLA4 т т.д.).

Аспекты развития иммунной терапии были представлены, в основном, группой молодых ученых из Новосибирска и Санкт-Петербурга. Доклад на тему «Противоопухолевая активность Т-клеток, экспрессирующих химерные рецепторы антигена CD19» был сделан П. Гершович (БиоКад, Санкт-Петербург). Представлен оптимальный производственный процесс продукции CD19-специфичных CAR T-клеток, а также стандартные тесты in vitro для оценки противоопухолевой активности в отношении целевых злокачественных клеток так, как это делается на предприятии БиоКад.

Анна К. Владимирова уточнила детали изготовления CAR-T-клеток в своем докладе «Подходы к nостроению CD1-химерного антигенсвязывающего домена CAR-клеток». Обсуждались вопросы оптимизации генных фрагментов ScFv с целью обеспечения высокой экспрессии антиген-связывающих доменов на CD19 Т-клеточных линиях.

Алексей Петухов (Санкт-Петербург), специалист из Медицинского центра им. В. А. Алмазова, сделал сообщение «Алгоритм поиска новых мишеней для CAR-T-клеточной терапии».

Антон Чикаев, иммуногенетик из Института молекулярной и клеточной биологии (Новосибирск) представил новую точку зрения на генно-манипулированные NK-клетки, т.е., клеточные линии NK-происхождения, способные блокировать молекулы CD47 на опухолевых клетках. Так называемые ECAR-YT клетки могут продуцировать блокаторы CD47/SIRPa, что усиливает уничтожение опуходевых клеток, по крайней мере - в мышиных моделях. Татьяна Беловежец, исследователь из того же института, продолжила обсуждение докладом «В поисках оптимальной NK-клеточной тинии в качестве носителя CAR». В целом, NK-клеточные линии считаются лучшими носителями химерных антигенных рецепторов (CARs) из-за ряда их биологических преимуществ по сравнению с CAR-T-клетками. Клеточная линия NK-92 рассматривается как наиболее перспективная и проходит клинические испытания в Германии и Китае. Кроме того, Андрей Горчаков представил свое видение альтернативных мишеней для CAR-клеток “CAR на базе аднектина: за и против" и показал потенциальные выгоды схем с применением гуманизированные FnCAR, вместо мышиных scFv-CARs, при воздействии на целевые молекулы PSCA или PSMA, VEGFR2, IGF-1R, CEA или иные маркеры, экспрессируемые в солидных опухолях. Модули Fn3 могут функционировать как антиген-распознающие модули химерных антигенных рецепторов (CAR). Эта тема была успешно развита С.Кулемзиным, который оживил надежды на клетки-естественные киллеры в качестве носителей CAR при современных достижениях в генном редактировании «Сочетание естественных киллеров с генным редактированием».

Основная программа симпозиума была открыта Мемориальной лекиией памяти Томаса Бюхнера, которую провел проф. Валерий Г. Савченко (Москва). Доклад касался лечения острого миелобластного лейкоза (ОМЛ), которое стало намного успешнее за последние десятилетия. Аллогенная ТГСК также значительно повлияла на резкое повышение долгосрочной выживаемости больных с ОМЛ, что было продолжением тактики «двойной индукции и поддерживающей терапии» - концепции, разработанной Т. Бюхнером на протяжении многих лет. Кроме того, факторы неблагоприятной цитогенетики, коморбидности, пожилого возраста пациентов и др. также имеют значение для прогноза и уровней безрецидивной выживаемости.

Лекция проф. Роберта П. Гэйла на тему «Является ли тестирование МОБ при ОМЛ величайшим открытием после открытия огня?» была посвящена неопределенности и ассоциативному характеру прогнозов, основанных на множестве параметров, в т.ч. минимальной остаточной болезни (МОБ), определяемой с помощью проточной цитометрии, ПЦР или NGS. Проф. Гэйл подчеркнул известные фундаментальные различия между статистикой и методами принятия решений клиницистами, что требует осторожности при интерпретации результатов оценки МЛОБ.

Проф. Арнон Наглер (Израиль) представил лекцию «Предотвращение и лечение рецидивов ОМЛ после аллогенной трансплантации стволовых клеток». Ввиду плохой выживаемости пациентов после рецидивов ОМЛ, предложено продолжать поддерживающую и профилактическую терапию после трансплантации, особенно у пациентов с лейкозами высокого риска или 
после кондиционирования сниженной интенсивности. Инфузии донорских лимфоцитов и некоторые новые препараты могут повысить выживаемость при ОМЛ.

Проф. Р. Хельманн (Германия) обобщил существующие данные в лекции "ХМЛ в 2018 с особьм вниманием к терминальной фазе». Иматиниб и другие ингибиторы киназ удлинили сроки прогрессии и развития бластного криза при хроническом миелоидном лейкозе (ХМЛ). Высокорисковые дополнительные хромосомные оказывают негативный эффект на выживаемость и тесно связаны с бластным кризом и прогрессией заболевания.

Иммунотерапия в онкологии - актуальная тема - обсуждалась профессором Х-И. Кольбом в его обзоре "Аллогенная трансплантация стволовых клеток для лечения солидных опухолей?» Инфузии донорских лимфоцитов сейчас регулярно используются для профилактики рецидивов при лейкозах, тем самым используя эффект «трансплантат против лейкоза». Специфические клеточные популяции, в т.ч. регуляторные Т-клетки, миелоидные супрессорные клетки, макрофаги 2 типа могут быть вовлечены на различных стадиях иммунного надзора и ответа. За последние годы успешно применяются таргетные препараты, в особенности ингибиторы $\mathrm{PD}-1$, для лечения меланомы и некоторых других иммуногенных опухолей.

Проф. А. Мадригал (Лондон, Великобритания) сделал доклад «Иммунобиология клеточной терапии и уникальных пуповинных клеток». Этот источник гемопоэтических стволовых клеток применяется на протяжении десятилетий. Клетки пуповинной крови (КПК) содержат большое число потенциальных противоопухолевых клеток, как, например, натуральные киллеры (NK), Т-регуляторные клетки(Treg), антиген-специфические Т-клетки и др. Описан ряд протоколов культивирования и размножения КПК, а также несколько клинических исследований. CAR-T-клетки, полученные из КПК, также являются перспективным средством терапии. Обсуждаются другие методы иммунотерапии, в т.ч. вакцинация неоантигенами и использование ингибиторов контрольных точек иммунитета. Обобщены и интересные данные о приложениях размноженных NK-клеток для иммунотерапии.

Лекция профессора А. Р. Цандера (Гамбург, Германия) «Клеточная терапия множественной миеломы - есть ли еще место для аллогенной трансплантации гемопоэтических клеток?» касалась новых подходов к лечению миеломной болезни. Рассматриваются два основных типа клеточной т ерапии или их последовательное применение (аутологичная ТГСК, аллогенная ТГСК), иногда с добавлением инфузий донорских лимфоцитов, что дает различную эффективность, судя по работам отдельных групп исследователей. Использование CART-клеток все еще находится в процессе клинических испытаний. Обсуждаются некоторые побочные эффекты (синдром выброса цитокинов, нейротоксичность) и возможные причины неудач этой иммунотерапии.

Информативная лекция «Oт макси до мини: сохранение баланса эффективности, токсичности и интенсивности» была представлена проф. Б. В. Афанасьевым (Санкт-Петербург). Он проследил вкратце историю
алло-ТГСК - от миелоаблативного кондиционирования с заменой костного мозга до лечения со сниженной интенсивностью с компонентами иммунотерапии, усиленной введениями донорских лимфоцитов. Эта тактика привела к повышению возраста пациентов, у которых стала возможной алло-ТГСК. Ввиду высокого риска рецидивирования, обсуждаются многочисленные виды «переходной» терапии до алло-ТГСК, например - при болезни Ходжкина (БХ). Успешные результаты при БХ получены с препаратом Брентуксимаб. Таким образом, применение режимов кондиционирования сниженной интенсивности, моноклональных антител, ингибиторов контрольных точек иммунитета в различных сочетаниях может быть эффективным и в ряде случаев - менее токсичным.

В ходе сессии «Различные аспекты ТГСК», проф. И. Маттссон (Стокхольм) сделал впечатляющий доклад под названием: «Аллогенная ТГСК - дьявол кроется в деталях: больше трансплантаций, улучшение исходов и снижение расходов». После перечисления ряда факторов, ведущих к ранней смертности после ТГСК, он указал на несколько убедительных причин для применения домашнего ухода за больными, что может снижать частоту осложнений и смертность в этом контингенте. И. Маттссон также говорил о потенциальной эффективности децидуальных стромальных клеток против РТПХ у пациентов.

Д-р Йохан Терлен (Стокгольм) с докладом «Результаты проспективного рандомизированного сравнительного исследования профилактики РТПХ CyA/Mtx u Tac/Sir nocле TГCK» показал сравнимую частоту исходов с применением CsA/Mtx у больных при HLA-совместимой, родственной и неродственной ТГСК. Он не обнаружил достоверных различий между 2 режимами по частоте вирусной реактивации или септицемий. Кроме того, динамика дифференцировки тимоцитов по маркерам TREC или KREC не зависела от типа профилактики РТПХ.

Интересная лекция "Гистопатологические и молекулярные находки в костном мозге при миелопролиферативной неоплазии (МПН) после ТГСК» была представлена прф. Хансом Крайпе (Ганновер). Рассматривался спектр множественных мутаций при МПН, а также их возможная клиническая значимость для развития миелофиброза. Долгосрочные первичный миелофиброз и истинная полицитемия часто имеют ведущие (драйверные) мутации МПН-типа. В то же время выраженный фиброз разрешается в сроки до 6 месяцев после успещной алло-ТГСК, что является хорошим патогистологическим маркером.

Несколько кратких сообщений о локальных достижениях сделали врачи НИИ детской онкологии, гематологии и трансплантологии им. Р. Горбачевой (Санкт-Петербург). Д-р О. Пирогова рассказала об $A L$-амилоидозе (современные подходы к диагностике и лечению) место ТГСК. Д-р М. Барабанщикова представила доклад «Место аллогенной трансплантации гемопоэтических стволовых клеток для пациентов с миелофиброзом в эру ингибиторов ЈАК1/JАК2». Д-р Н. Цветков описал свои наблюдения, касающиеся «Пре- u nocm- 
трансплантационная терапия у взрослых пациентов с МДС».

Проф. М. Абекасис (Лиссабон) сообщил интересные данные о развитии аллогенной трансплантации костного мозга в Португалии (1987-2016): «30 лет ТГСК: как она развиваласв и уроки начего иентра». Доклад включал данные о 1854 трансплантированных пациентах (793 алло-ТГСК, в основном - от родственных доноров). Большой регистр доноров (ок. 400000 чел.) существует теперь в Португалии. Общая и безрецидивная выживаемость повысилась за последнее десятилетие.

Проф. Т. Рууту (Хельсинки) представил содержательный обзор «Современные достижения в трансплант-ассоциированной тромботической микроангиопатии (TA-TMA)» связанной с посттрансплантационным эндотелиальным повреждением и сложной для диагноза. Обсуждается роль шистоцитоза в качестве диагностического маркера. У некоторых пациентов с ТА-ТМА, активирована система комплемента, что делает возможным лечение Экулизумабом.

Д-р Кен Ишияма (Япония) изложил свою точку зрения в лекции "Посттрансплантационная иммунная недостаточность гемопоэза: Частая причина поздней недостаточности трансплантата у больных с полным донорским химеризмом». Патогенез поздней недостаточности гемопоэтического трансплантата остается неясным. В некоторых случаях (сходных с апластической анемией) она связана с дефицитом якорного GPIAP (клетки типа ПНГ-пароксизмльной ночной гемоглобинурии), и/или наличием лейкоцитов с отсутствием аллелей HLA (HLA-LLs). Иммунная костномозговая недостаточность может быть излечена посредством иммуносупрессивной терапии, без повторной ТГСК.

Д-р Д. Моторин представил доклад «Восстановление гемопоэза после наплоидентичной трансплантации стволовых клеток», касающийся факторов, влияющих на клинические исходы у пациентов, трансплантированных по поводу ОЛЛ, ОМЛ и ХМЛ. Гаплоидентичная ТГСК ассоциирована с более длительным восстановлением тромбоцитов, по сравнению с совместимой родственной ТГСК.

Сессия Фундаментальные исследования открылась лекцией д-ра М. Борсета (Норвегия) на тему: «Гипогликемия и гипоксия: как может выживать раковая клетка?». Он обсуждал ряд соответствующих биохимических положений (преобладание гликолиза в раковых клетках, особая биосинтетическая роль серина и глицина с обогащением Glute1 and CD98; усиление гликолиза и высокая продукция АТФ под влиянием PRL-3), как было показано на примере клеток миеломы. Сделан вывод о том, что PRL-3 и энзимы серин-глицинового пути могут быть перспективными мишенями для лечения рака.

Проф. Б. Фезе (Гамбург) в своем докладе «Генетическое маркирование для изучения злокачественных процессов» коснулся применения генного маркирования для совершенствования и развития генной терапии, в особенности - при работе с лентивирусными векторами (LeGo-векторы). При этом рассматриваются: цветное маркирование (RGB) для анализа клонального ростак, и ДНК-штрих-кодирование для отслеживания злокачественных клонов (Штрих-кодированные LeGO-векторы). Генетическое штрих-кодирование используется, например, для изучения клональности в клеточных культурах. Оптическое штрих-кодирование флуоресцентными белками теперь внедряется в работах in vitro. Далее, д-р Клаудиа Ланге сделала свое сообщение на тему: «Экстраклеточные частицы из мезенхимных стволовых клеток (МСК) в гемато-онкологии» относительно сложного белкового состава и спектра активации генов во внеклеточных частицах (ВКЧ) полученных из мезенхимных стволовых клеток, а также позитивных эффектов этих частиц на стволовые клетки in vivo, например - повышение выживаемости облученных мышей.

Лекция «Негенотоксическое кондиционирование для трансплантации стволовых клеток и генной терапии/редактирования» была представлена профессором Х.-П. Кимом (Сиэтл, США) и касалась особых протоколов кондиционирования прия генной терапии неопухолевых заболеваний. На основе экспериментов с мышами автор предложил схему кондиционирования, основанную на воздействии иммунотоксина, которая облегчает приживление в модели с аутологичной трансплантацией, сравнимой с известным кондиционированием на основе циклофосфамида.

Проф. Н. Мамаев (Санкт-Петербург) в своей лекции «Oпыт и перспективы молекулярного мониторинга, основанного на серийном измерении уровней экспрессии гена WT1 для оценки алло-ТГСК и эффективности терапии при ОМЛ» докладывал об экспрессии WT1 как маркере рецидива лейкоза. Он сделал вывод о том, что определение экспрессии мРНК WT1 возможно у всех больных с ОМЛ при подготовке к трансплантации, что предполагает более широкое ее использование до и после ТГСК.

Д-р А. Тимин сообщил некоторые экспериментальные данные в своем докладе «Функиионализация костномозговых мезенхимных стромальных клеток с помощью мультифункциональньх микрокапсул для таргетной доставки препаратов». Авторы предлагают новую концепцию многослойных полиэлектролитных микрокапсул, в качестве носителей препаратов, активируемых различными физическими воздействиями. Показаны их взаимодействия с мезенхимными стволовыми клетками человека.

Педиатрическая сессия началась лекцией проф. Александра Г. Румянцева (Москва) под названием: «Перспективы развития педиатрической онкологии в России». Лекция содержала много сведений об эпидемиологии раковых заболеваний у детей в России и в мире, успехах в лечении ОЛЛ, лимфом и ряда солидных опухолей у детей. Особое внимание было привлечено к организационным аспектам педиатрической онкологии/ гематологии в России. В последующем докладе проф. А. Масчан (Москва) представил ряд новых данных о профилактике недостаточности и дисфункции трансплантата в педиатрической клинике.

Проф. Б. Пинто-Симоэс (Бразилия) поделилась своим клиническим опытом по теме: «Трансплантация ство- 
ловых клеток при множественном склерозе (МС)»инвалидизирующем заболевании, которым в мире болеют ок. 2,5 млн. человек. Концепция перезагрузки иммунной системы позволила внедрить аутологичную ТГСК для ее лечения. Часть больных с долгосрочным полным ответом была довольно высокой по критериям шкалы физической активности EDSS.

Проф. Ольга Алейникова (Минск, Республика Беларусь) выступила с лекцией "Достижения и перспективы онкологии и гематологии детского возраста в Республике Беларусь». Эта программа началась в конце 90-х гг. Первые достижения были при лечении ОЛЛ, лимфомы и ОМЛ, с применением европейских протоколов. Экстракорпоральный фотоферез (ЭКФ) и мезенхимные стволовые клетки использовали в качестве дополнительной терапии. Среди перспективных подходов рассматривается терапия NK-клетками от гаплоидентичных доноров. За 20 лет в Беларуси выполнено свыше 1000 ТГСК.

Д-р И. Маркова (Санкт-Петербург) сообщила свои данные в докладе «Преодоление резистентности при ОЛЛ y детей посредством блинатумомаба», где были предложены соответствующие режимы и временной график для применения блинатумомаба.

Проф. М. Масчан (Москва) представил «Первый опьы применения CAR-T-клеток против CD19 при рецидивах и резистентном ОЛЛ у детей в иентре Д. Рогаче$\boldsymbol{в a » . ~ И с с л е д о в а н и е ~ п р о в о д и л и ~ с ~ и с п о л ь з о в а н и е м ~ а у т о л о - ~}$ гичного лейкаферезного продукта, обогащенного CD4/ CD8 клетками, которые трансдуцировали вектором Lentigen, с дальнейшим размножением их в закрытой системе. Такое производство CD19 CAR-T-клеток на месте применения выполнимо и эффективно. Первые 3 пациента были безопасно пролечены, и наблюдался очевидный клинический эффект.

Д-р А. Лавичка (Вена, Австрия) представила доклад «РТПХ и ЭКФ: аспекты будущих исследований», касающийся важных аспектов кондиционирования и РТПХ при трансплантации у детей, методов профилактики РТПХ. Обсуждаются несколько руководств по экстракорпоральному фотоферезу при хронической РТПХ, а также преимущества и недостатки такого терапевтического подхода

Проф. Н. Субботина (Москва) в своем сообщении «ТГСК в педиатрической онкологии: пути повышения эффективности» рассказала о современном использовании ТГСК с различной эффективностью при солидных опухолях, лейкозах и лимфомах у детей. Рассмотрены вопросы персонализации терапии в отношении возраста пациента, характеристик опухолей и способов адекватного лечения. Применяются индивидуальные планы лечения для медуллобластомы, при болезни Ходжкина и других злокачественных заболеваниях у детей.

Д-р К. Киргизов (Москва) представил доклад под названием «Трансплантация гемопоэтических стволовых клеток при незлокачественных гематологических заболеваниях и врожденных очибках метаболизма $у$ детей», где описан опыт аллогенной ТГСК при лечении тяжелых анемий, врожденного дискератоза, болезни Гурлер и других незлокачественных заболеваний. Персонализированный режим кондиционирования и правильный подбор донора позволяют получить оптимальные результаты с долгосрочными ремиссиями.

Серия коротких сообщений на педиатрической секции была проведена молодыми врачами НИИ детской онкологии, гематологии и трансплантологии им. Р. М. Горбачевой, в частности - доклад д-ра А. Осиповой об исходах алло-ТГСК у детей с миелодиспластическим синдромом (МДС); д-ра А. Козлова о тактике ведения резистентных случаев лимфопролиферативных заболеваний с применением иммунотерапии; д-ра О. Голощапова о трансплантации фекальной микрофлоры у больных после ТГСК; д-ра Т. Быковой - о профилактике и лечении РТПХ у детей после ТГСК; д-ра О. Паиной - с собственными данными об алло-ТГСК от гаплоидентичных доноров у детей с лейкозами высокого риска. Д-р П. Кожокарь сообщила о результатах повторных аллогенных ТГСК у детей с онкогематологическими заболеваниями высокого риска.

Мемориальная лекция памяти Р. М. Горбачевой «Трансплантация гемопоэтических стволовых клеток при ОЛЛ: принятие решений по данным МОБ и NGS» была представлена профессором Д. Хельтцером (Франкфурт, Германия). Доклад содержал данные об исследовании диагностических маркеров (перестройки TCR/IgH, поверхностные маркеры, слитные гены и т.д.), а также о потенциальных мишенях терапии, таких, как маркеры поверхности CD20, CD19, CD22, CD33 или генные аберрации (BCR-ABL, мутации Flt3). В этом плане, секвенирование следующего поколения является наиболее точным средством поиска новых маркерных мутаций. Ряд новых препаратов, например, венетоклакс рассматриваются в качестве лечения при рецидивах ОЛЛ.

Традиционная Секция медицинских сестер и Секция медицинской и социальной реабилитации также состоялись в рамках нашего Симпозиума и привлекли значительное внимание участников и аудитории. 